\title{
A Review of Knowledge Management Based Career Exploration System in Engineering Education
}

\author{
Varekan Keishing \\ Research Scholar, National Institute of Technical Teachers Training \& Research, (NITTTR), Chennai-600113, India \\ E-mail: varekan.k@gmail.com

\section{S. Renukadevi} \\ National Institute of Technical Teachers Training \& Research, (NITTTR), Chennai-600113, India \\ E-mail: bmrenuka@gmail.com
}

\begin{abstract}
Knowledge sharing has become an important tool in every organization's success story today. Various knowledge management applications has been carried out recently in many sector like health care, university, banking, construction etc. and it has brought significant improvements. However minimal research is done on career development and as such Knowledge management in career exploration in Engineering Education has not been carried out till date. In India, most of the curriculum and pedagogy does not suit with the real time job environment and this caused many graduates to remain unemployed every year. To meet the gap, this paper attempts to highlight the works on the various existing career exploration and knowledge management techniques. The author collected relevant literature from 2010 to 2015 with the objective to find out a way to combine the two disciplines of career exploration and knowledge management to enhance the career awareness and career exploration system with the application of knowledge management techniques. From the study, the researcher found four conclusions: (i). Education and work/career are separated into different world; (ii). Career exploration enhances student's career awareness; (iii). Knowledge management technique adds efficiency and enhances curriculum; (iv). The research efforts in knowledge management (KM) and career exploration are sparse and no such literatures are available on knowledge management in career exploration currently. This research may add to the development of an efficient knowledge management based career exploration system for engineering education.
\end{abstract}

Index Terms-Tacit Knowledge, Explicit Knowledge, Knowledge Sharing, Knowledge Elicitation, Knowledge Management, Career Exploration, KMCES.

\section{INTRODUCTION}

Various knowledge management applications has been carried out recently in many sector like health care, university, banking, construction etc. and has brought significant improvements in the services and product development. The research literature of Knowledge Management in Career exploration is very rare. In India, the field of career exploration as the study, with the use of knowledge management systems was an interesting domain, as student's career skills and company requirements skills vary and also there are mushrooms of technical institutions producing thousands of IT graduates every year and many remain unemployed. The following literature review attempted to link knowledge management in career exploration. The literature review structure is given in fig 1 .

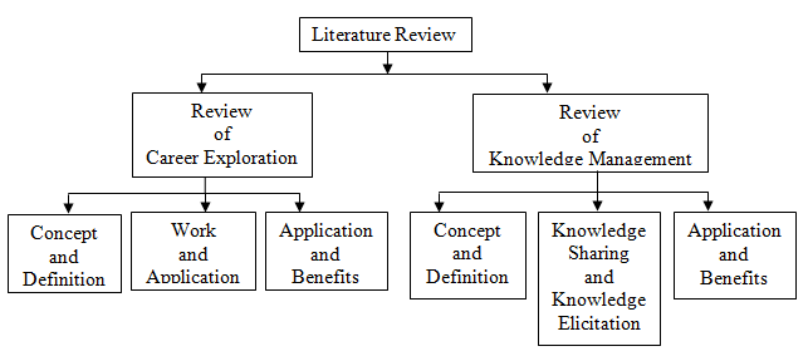

Fig.1. Literature Review Structure

\section{CONCEPT \& DEFINITION OF CAREER EXPLORATION}

Career Exploration is the process of exploring the variety of occupation and its eligibility qualification and criteria; skills like technical skill, soft skill; realities of working environment like timing, location of industry, nature of work; salary and allowance; bond agreement (if any available in the company) etc., during the course of study that will help the students to acquire, build and prepare skills requirements in advance before entering the real time work. Many researchers has put forward the concept and definition of career exploration and also from the literature of Maria \& Luisia [1], with further literature review, the researcher found the following definition of career exploration as shown in table 1 below. 
Table 1. Concept/Definition of Career Exploration

\begin{tabular}{|c|c|c|}
\hline Sl.No & $\begin{array}{c}\begin{array}{c}\text { Concept/Definition of } \\
\text { Career Exploration }\end{array} \\
\end{array}$ & Author/Year \\
\hline 1 & $\begin{array}{l}\text { Originated in theories such as Krumboltz's } \\
\text { learning theory of career choice and } \\
\text { counselling, considers career exploration } \\
\text { as a type of information-seeking behaviour } \\
\text { or as a career problem-solving behaviour. }\end{array}$ & $\begin{array}{c}\text { Krumboltz, } \\
1979 \text { [2] }\end{array}$ \\
\hline 2 & $\begin{array}{l}\text { The concept of career exploration was } \\
\text { define as a major life stage, that of } \\
\text { adolescence (from ages } 14 \text { to 24), and } \\
\text { comprising the career developmental tasks } \\
\text { of crystallizing, specifying and } \\
\text { implementing an occupational choice }\end{array}$ & $\begin{array}{c}\text { Ginzberg et. } \\
\text { al, } 1951 \text { [3]; } \\
\text { Super, } 1957 \\
\text { [4] }\end{array}$ \\
\hline 3 & $\begin{array}{l}\text { Career exploration may be defined as as } \\
\text { purposive behavior and conditions that } \\
\text { afford access to information about } \\
\text { occupations, jobs, or organizations that } \\
\text { was not previously in the stimulus field }\end{array}$ & $\begin{array}{l}\text { Stumpf et. al, } \\
1983 \text { [5], } \\
1984 \text { [6], } \\
\text { Berlyn, 1960 } \\
\text { [7], 1963 [8], } \\
\text { 1965 [9], } \\
\text { Jordan, 1963 } \\
\text { [10] }\end{array}$ \\
\hline 4 & $\begin{array}{l}\text { Career exploration may be defined as the } \\
\text { process of generating and assimilating } \\
\text { career information relating to self and the } \\
\text { world of work, has long been recognized } \\
\text { as an integral element in reaching a career } \\
\text { decision }\end{array}$ & $\begin{array}{c}\text { Atkinson \& } \\
\text { Patricia, } 1988 \\
{[11]}\end{array}$ \\
\hline 5 & $\begin{array}{l}\text { Career exploration encompasses a wide } \\
\text { range of activities including the gathering } \\
\text { of information and knowledge about job } \\
\text { searching, planning, opportunities, and } \\
\text { careeroptions. }\end{array}$ & $\begin{array}{c}\text { Levi \& } \\
\text { Ziegler, } 1993 \\
\text { [12]. }\end{array}$ \\
\hline 6 & $\begin{array}{l}\text { Career Exploration involves activities that } \\
\text { attempt to relate knowledge of oneself to } \\
\text { the external world and the internal world } \\
\text { (e.g., knowledge and mental structures) } \\
\text { and can be described as an openness to } \\
\text { experience that fosters self-discovery and } \\
\text { prompts reflection about environmental } \\
\text { action }\end{array}$ & $\begin{array}{c}\text { Bluestein \& } \\
\text { Flum, } 1999 \\
\text { [13]. }\end{array}$ \\
\hline 7 & $\begin{array}{l}\text { Career exploration process helps the } \\
\text { students to explore a variety of } \\
\text { occupational opportunities, learn the } \\
\text { realities of the workplace, and identify both } \\
\text { the technical skills and individual qualities } \\
\text { that they will need to succeed }\end{array}$ & $\begin{array}{l}\text { NHDE, } 2000 \\
{[14] .}\end{array}$ \\
\hline 8 & $\begin{array}{l}\text { Classified career exploration into two } \\
\text { distinct forms. First, Diversive career } \\
\text { exploration and Second, Specific career } \\
\text { exploration. Diversive career involves } \\
\text { learning broadly about the world of work } \\
\text { and the self, whereas specific career } \\
\text { exploration involves an in-depth } \\
\text { investigation focused on aligning one's } \\
\text { perceptions of self and career prospects. }\end{array}$ & $\begin{array}{l}\text { Erik J. Porfeli } \\
\text { and Vladimir } \\
\text { B. Skorikov, } \\
2010[15] .\end{array}$ \\
\hline
\end{tabular}

\section{REVIEW OF WORK \& EDUCATION}

The skills required by the industry and the skills produced by the educational institutions were not match and this brings disparity in the work and education. One should aware that in the exploration stage individuals initiate thoughts and behaviors that will likely lead to a future career choice. If students in career exploration stage are given an opportunity to avail career knowledge at the right time, they may prepare accordingly. But Lowe \& Toney [16] indicated that academic advisement is often considered a minor activity at most colleges and universities. Also in 2012, Andreas B. \& Hiroshi S. [17], in their work "Employability and Skill Set of Newly Graduated Engineers in India", stated that skill shortage remains one of the major constraints to continued growth of the Indian economy. This study did an employer survey to address the knowledge-gap and found that skill demands differ for professional skills across economic sectors, company sizes, and regions and suggest that engineering education institutions should: (i). seek to improve the skill set of graduates; (ii). emphasize soft skills, (iii). refocus the assessments, teaching-learning process, and curricula and (iv). interact more with employers to understand the particular demand for skills in that region and sector. Also Stone J. [18] in 2011, spoke about the skills required from the market point of view and to develop those skills in schools so that students will be career ready. The skills to be career ready by the students are: academic knowledge, employability skills and technical skills. But to meet these skill needs, teaching academics in school have to be in occupational context, only then it will bring improvement in the learning and career awareness of the students.

In 2013, Chithra. R, [19], in the article "Employability Skills -A Study on the Perception of the Engineering Students and their Prospective Employers", studied the perception of students and employers together and found that there is significant difference between them. This disparity between students and the employer makes the students mostly unemployable. It can be pointed out from this article that the industry needs and the institute product were not match. In 2013, SAHDS [20] in the work "International Comparative Study: Engineering Education in India", found out that there are limited reliable information resources available in engineering education and this makes it difficult for policy makers, researchers, and stakeholders to conduct robust and meaningful analysis of the engineering education system. This limitation may be eradicated if University-Industry partnerships takes place in the country. Again in 2015, OECD [21], also found out in their study that work and education are often separated into two different worlds. The study makes very clear that where education and the labor market co-exist as two separate worlds, it is very difficult for young people to manage the transition from one to the other. One should aware that young people are best integrated into the world of work when education systems are flexible and responsive to the needs of the labour market, employers are engaged in both designing and providing education programmes, young people have access to high-quality career guidance and further education that can help them to match their skills to prospective jobs, and institutionalized obstacles to enter the labor market, even for those with the right skills, are removed. Some of the recent review of career exploration and its application that may extend help to this research are discussed in the following sections.

\section{CAREER EXPLORATION APPLICATION AND ITS BENEFITS}


In 1984, Stumpf et al., [6] carried out a longitudinal research study on 78 business school students and found that the application of the process of career exploration enhances interview readiness in the business school students, which relates to interview performance and job offers. But this study deal with few students and further research is required by applying larger sample of heterogeneous groups to examine the relationship between career exploration and interview readiness. In 1992, Sakar V. Kamarthi et. al, [22], also proposed a model called ADVISOR-An Expert System for the Selection of Courses. This system helps students to select course plan and record keeping. It also aids students to complete the degree requirement but the study did not speak about career/work related guidance.

In 2000, Denise F.B. \& Christine R.[23], in their study of homogenous participants of sample, found that career exploration gives higher level of career decision making, self-efficacy, personal growth initiative, explorational stress, external search instrumentality and autonomous motivated process. In addition gender differences were seen among male and female in career exploration. Male reported significantly higher levels of the control orientation in motivational process than female, indicating more engagement in career exploration behavior but study can be extended to heterogeneous group of study to generalize the study.

In 2005, Janice W. \& Maggie B., [24], in their study of nursing as the sample study on nursing baccalaureate education career development programs also found that students who participated in career planning and development program in the earlier years were significantly more active in the process of career planning and development, and reported greater confidence in their ability to make career related decisions than those who did not participate in such a program at that stage of their nursing education. Similarly in 2008, Esters [25], in the study, "Influence of career exploration process behaviors on agriculture students' level of career certainty", also found that agriculture students level of career certainty increases on the extend of career exploration involving self and occupational exploration. While in 2011, Kelly K. Pargett, [26] in the study of business administration college as the sample study, found that there was a relationship between academic advising and student development; also there was a relationship between academic advising and student satisfaction with college. But this study may include other heterogeneous groups of sample to generalize the study.

In 2013, Stephanie R. Easterday [27], in the study, "Academic advising: A study of the impact of academic advising on student satisfaction", carried out a study to determine if Rowan University undergraduate students are satisfied with the academic advising services being provided to them by the Center for Academic Advising and Exploration (CAAdE). The study found that, students are satisfied with the academic advising they are receiving and report favorable impressions of their advisors. While in 2014, Adeel K. \& Jessica W. [28], in the study, "Role of Academic Advisors in the Success of
Engineering Students", found that well advised students will continue enjoying their time as a college student as they are well informed and aware of what it will take to be successful. In addition, the study further highlighted the need to successfully serve all the students and to increase the number of academic advisors in the institution.

\section{CONCEPT OF KNOWLEDGE MANAGEMENT}

Education is to make people aware of concepts, skills and competencies that suit the real time work environment in the Industry. Knowledge is the experience gain by the individual/organization from the work. To distinguish data from information and from knowledge Alavi \&Leidner [29] as cited in Rao R. Nemani [30], gave us clearly as below fig. 2 .

\section{When individual posses such information into their brain and apply it \\ to take action or make decisions then it will be considered as knowledge

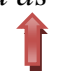 \\ Once the data is systematically processed, organized or given structure, it turns into information \\ Data is the representation of raw numbers and facts}

Fig.2. Data, Information \& Knowledge

Table 2. Definition of Knowledge Management

\begin{tabular}{|c|c|c|}
\hline Sl.No & Definition of knowledge management & Scholars \\
\hline 1 & $\begin{array}{l}\text { Knowledge management deals with } \\
\text { creating, securing, capturing, } \\
\text { coordinating, combining, retrieving, and } \\
\text { distributing knowledge. }\end{array}$ & $\begin{array}{l}\text { Liebowitz, } \\
2000 \text { [32] }\end{array}$ \\
\hline 2 & $\begin{array}{l}\text { Knowledge management is a discipline } \\
\text { that promotes an integrated approach to } \\
\text { the creation, capture, organization, } \\
\text { access and use of an enterprise's } \\
\text { intellectual capital on customers, } \\
\text { markets, products, services and internal } \\
\text { processes. }\end{array}$ & $\begin{array}{l}\text { Abell \& } \\
\text { Oxbro, } 2001 \\
{[33]}\end{array}$ \\
\hline 3 & $\begin{array}{l}\text { Knowledge management directs } \\
\text { acquiring, storing, adding value to and } \\
\text { deploying the intellectual capital of the } \\
\text { firm's professionals. }\end{array}$ & $\begin{array}{l}\text { Ezingeard, } \\
\text { Leigh \& } \\
\text { Chandler- } \\
\text { Wilde, } 2000 \\
{[34]}\end{array}$ \\
\hline 4 & $\begin{array}{l}\text { Knowledge management (KM) refers to } \\
\text { the methods and tools for capturing, } \\
\text { storing, organizing, and making } \\
\text { accessible knowledge and expertise } \\
\text { within and across communities. }\end{array}$ & $\begin{array}{l}\text { Mack, } \\
\text { Ravin,\& } \\
\text { Byrd, } \\
2001[35]\end{array}$ \\
\hline 5 & $\begin{array}{l}\text { "Knowledge management (KM) } \\
\text { system" is a phrase that is used to } \\
\text { describe the creation of knowledge } \\
\text { repositories, improvement of knowledge } \\
\text { access and sharing as well as } \\
\text { communication through collaboration, } \\
\text { enhancing the knowledge environment } \\
\text { and managing knowledge as an asset for } \\
\text { an organization. }\end{array}$ & $\begin{array}{l}\text { Rusli } \\
\text { Abdullah et. } \\
\text { al., } 2005 \\
\text { [36] }\end{array}$ \\
\hline
\end{tabular}


Knowledge is classified into two types: 1) Tacit knowledge and 2) Explicit knowledge. Tacit knowledge is the knowledge gained by experience and it is hard to elicitate while explicit knowledge are those knowledge which are readily available for use. From Lisa Soon [31], and from the literature survey, few Knowledge Management (KM) definitions from some scholars are shown in table 2 below.

There are over 100 identified published definitions of knowledge management and from the process or technology perspective, knowledge management is the concept under which information is turned into actionable knowledge and made available effortlessly in a usable form to the people who can apply it (Information Week, Sept. 1, 2003 as cited in Kimiz Dalkir [37]). Knowledge Management is a multidisciplinary field and various studies were done by many scholars in different domain in the past years. Some of the recent review of knowledge management and its application that may extend help to this research are discussed in the following sections.

\section{KnOWledge Management Application \& ITS BENEFITS}

The application of knowledge management in the organization can enhances the performance in services and product development. According to Abdel Nasser $\mathrm{H}$. Zaied et. al [38], in 2012 indicated that there is a great correlation between knowledge management capabilities and organizational performance. The following study highlights some of the knowledge management application and its benefits.

In 2002, Alison \& Stephen [39], in the article "Knowledge management in careers services: implications for Connexions managers" indicated that careers services support the provision of careers education within educational institutions to provide young people with the skills and knowledge needed to make informed career decisions at the many transition points they face in their lives. The participants of the research were 123 managers in career services organizations. But if client/students sample also were involved in the study to get their thoughts and views, than it may be more effective.

In 2003, Kimberly Gustafson [40], in the study, "A Case Study: Knowledge Management Systems to Enhance a Nursing Curriculum" indicated that it enhances student learning by: providing an opportunity to create content, teaching effective patient education, reaching learners-at-large on the web and participation in a knowledge building community. It also further stated that integrating the knowledge management system as an educational technology into nursing curricula is a dynamic and innovative teaching strategy.

In 2006, Balirwa, Moses [41], in the article "An information portal for career guidance: the case of ordinary level in Uganda" stated that this information portal contains a knowledge base with information gathered from human experts on career guidance to assist in offering career guidance to students, especially to those in ordinary level secondary schools in Uganda, who are always in dire need of choosing a professional line and where decision at such a level is so critical. This study focused on school alone and may include engineering colleges or universities to generalize the study.

Again in 2006, Oktri \& Kadarsah [42], in the study, "Nurse Knowledge Management Based On Expert System", has proposed a system that will help and enhances nurse knowledge management like about the career path, knowledge transfer and sharing among them. Also Marjan M \& Norizan M.Y [43] in 2010 talked about the development of web portal as a knowledge management system in the universities. This portal will provides a rich space to share and search information as well as communication services like free email or content provision for the users. The main aim of this knowledge portal is to discover the university needs and to help user in getting the required information. But the study seems general and it could be done for specific domain for efficiency.

In 2011, Anand Kumar N. V [44], in the research thesis "Design and development of metamodel for knowledge management in higher education domain", stated that higher education plays a vital role in creating a knowledgeable society. But the author further argued that universities teaching a curriculum and syllabus based education "by the book" alone may not solve the complex questions of the future, but by applying Knowledge Management, Universities can play a strategic role in the economic and social development of the country. This research study gives us a glue that industry and educational institutions together may bridge for the better career knowledge sharing.

While according to Parul D. Aggarwal et. al [45] in 2011, in one of the article, "Enhancing Curriculum and Research in Higher Education with a Strategic Use of Knowledge Management", indicated that universities and other higher educational institutions are the power house of knowledge and there are hidden, untapped reservoirs of intelligence that exist. The author further stated two important aspects of Knowledge Management (KM) in Institution of Higher education i.e., i) to acquire new knowledge and ii) to disseminate knowledge. But to achieve this, effective curriculum development and enhancing research may be implemented in the institution which in turn may help to create new knowledge and disseminate through portal, blog, repository etc.

\section{REVIEW OF KNOWLEDGE SHARING}

Knowledge sharing and exchanging enhances ones knowledge and in turns help to create new knowledge in the organization. In few literature like NKC, 2009 [46], it indicated the importance of knowledge sharing i.e. availing access to knowledge is the most fundamental way of increasing the opportunities of individuals and groups knowledge. Having said of the advantages of knowledge sharing, the study further suggested that it is essential to revitalize and expand the reach of knowledge in the society. Likewise Ulka Toro \& Milind J. J [47] in 
2013, also indicated that tools like Information \& Communication Technology (ICT) in knowledge management could play important roles in sharing, exchanging and disseminating knowledge and technologies in the higher education.

\section{REVIEW OF KNOWLEDGE ELICITATION}

Knowledge elicitation or acquisition is the process of extracting knowledge from various sources with the application of different techniques like interview, survey, email etc. In 1999, Kathleen K. Molnar \& Ramesh Sharda [48], in their study, "Using the Internet for knowledge acquisition in expert systems development: A case study", stated that Internet as a knowledge source give major advantages in extracting knowledge like the availability of multiple experts in multiple domains, the interaction of domain experts and end user, time/cost savings and convenience. While in 2010, Rao R. Neman [30] did a comprehensive review of literature and found that there is a connection between the computer technologies and their role in knowledge acquisition in an organizational setting. However knowledge sharing and elicitation will not be successful until and unless human is involved.

\section{Why KNOWLEDGE MANAGEMENT MATTERS IN CAREER EXPLORATION?}

India has thousands of Information Technology professionals working in the industry and they are the knowledge carrier. Knowledge resides in the person working in the organization and once person retires; his knowledge also retires as well. In 2012, Andreas Blom \& Hiroshi Saeki [17], indicated that there was an increasing demand for career skill information from teachers, administrators, and policy makers. According to YU Jianli \& Qu Bo [49], the development of career management in the knowledge-based economy era has brought about great changes in career management like career model, career development process, career stages and subjects of career management. While Arumugam Rathinavelu [50], in the article, "Design of Knowledge Management System(KMS) for Higher Education: Study", indicated the need and demand for using ICT to develop a knowledge share tool to help students to get information about curriculum, assignments, test, lecture notes etc. and so on.

Many researchers also suggested that new standard of career success should be adopted in knowledge-based economy era [51]. If engineers are given an education comprehensively with deep set of skills that are in demand in the market than it would be of tremendous importance for the employability of individual engineer and for the country's development [17]. The responsibilities common to all Engineering Institutions is to provide placement to the students but the employability skills of students are such that they are not readily employable. Curriculum of engineering education includes no explicit representation for career awareness and there exist minimum knowledge management in education. To my knowledge, Knowledge management in career exploration in Engineering Education has not been carried out till date and as such there is no knowledge management in existence for career development. In one of our study in 2012, Varekan Keishing \& Renukadevi [52], $92.5 \%$ of B.E Computer science engineering and B.Tech IT students have stated that they are in need of career knowledge to explore. It is a time to ponder by the stakeholder to aware that the pedagogy offered to the students in the institutions will reflects in the performance of the fresher when they join the real time work after graduation [53]. Therefore according to Bartley \& Robitschek [54] stated that if individuals do not successfully complete the tasks of career exploration stage in their course of study, they may flounder when it is time to enter and stabilize in an occupation. Thus if one gets an opportunity to interacts more with employers than they will understand the particular demand for skills in that region and sector [17]. This triggered my interests for research in Knowledge Management Based Career Exploration System, which can be aid user in career exploration.

\section{DisCUSSION \& CONCLUSION}

In this paper, the author tried to combine the two disciplines of career exploration and knowledge management by reviewing the various literatures. Most of the career exploration literatures reviewed were carried out in the population of colleges, universities, schools, nursing, and agriculture students, mainly on the basis of the prediction relative to career behavior. Career exploration for engineering education specifically in Computer Science \& Engineering and Information Technology students have not yet done till today. Also hundreds of knowledge management applications papers were also reviewed in different domain, to study the efficiency of the application of knowledge management. The researcher found that there is a knowledge gap between educational institute and industry. Also skills required for the real time job were highlighted (Andreas Blom. \& Hiroshi Saeki., 2012; Stone J., 2011), but the industry skills requirements needs and the educational institutions skills productions were found mismatching [19]. Also according to OECD in 2015 [21], it indicated that education and work are separated into different worlds and this makes it difficult to bring educational institution and industry together. While in 2013, SAHDS [20], stated that there are very limited information resources available on engineering education, therefore some scholars like Stumpf Stephen A. et al. 1984 [6]; Sakar V. Kamarthi et. al, 1992 [22]; Denise F. \& Christine, 2000 [23]; Janice W. \& Maggie B., 2005 [24]; Esters Levon T. 2008 [25]; Kelly K. Pargett, 2011 [26]; Stephanie R. Easterday, 2013 [27]; Adeel K. \& Jessica W., 2014 [28] has carried out a comprehensive study on the application of career exploration and found out that career exploration enhances interview readiness, career 
knowledge and awareness to the students in the long run.

According to Zaied et. al., [38] in 2012, the application of knowledge management improves organizational development and this same idea of knowledge management application enhancing organization development was reported in the study of Alison \& Stephen [39] in 2002; Kimberly Gustafson [40] in 2003; Balirwa, Moses [41] in 2006; Oktri \& Kadarsah [42] in 2006; Marjan M \& Norizan M.Y. [43] in 2010; Anand k [44] in 2011; Parul D. et. al. [45] in 2011; NKC [46] in 2009; YU Jianli \& Qu Bo [49]; Arumugam Rathinavelu [50]; Varekan K., Renukadevi [52] in 2012, and it also clearly emphasized the importance of knowledge management and enhancements in organizational development like improving administration, curriculum development, industry-institution knowledge sharing. But to support acquiring and sharing of knowledge one can use Internet and computer technologies as stated by Ulka Toro \& Milind J. J [47] in 2013; Kathleen K. Molnar \& Ramesh Sharda [48] and Rao R. Neman [30].

Thus from the study, the researcher found four conclusions: (i). Education and work/career are separated into different world; (ii). Career exploration enhances student's career awareness; (iii). Knowledge management technique adds efficiency and enhances curriculum; (iv). The research efforts in knowledge management (KM) and career exploration are sparse and no such literatures are available on knowledge management in career exploration currently. One way to increase students' level of career certainty is to mainly focus on the extent of career exploration [25] with the knowledge management techniques application. The present research added to the current research study in several ways. After studying literature of the importance of career exploration and the advantages of knowledge management application in different field makes way for the first time to combine two disciplines viz. career exploration and knowledge management to developed an efficient knowledge management based career exploration system (KMCES) for engineering education.

\section{FURTHER WORK}

In this paper a review of career exploration and knowledge management was carried out with an attempt to link the two disciplines to develop an efficient knowledge management based career exploration system. In future, the researcher will develop a Knowledge Management Based Career Exploration System (KMCES) framework and design a KMCES prototype model.

\section{REFERENCES}

[1] Maria \& Luisa, (2003). Guidance theory and practice the status of career exploration. British Journal of Guidance \& Counselling.

[2] Krumboltz, J.D. (1979). A social learning theory of career decision making. In: MITCHELL, A.M., JANE, G.G. \& KRUMBOLTZ, J.D. (Eds), Social Learning and Career Decision Making (pp. 19_49).
[3] Ginzberg, E., et. al., (1951). Occupational Choice: an Approach to a General Theory. New York: Columbia University Press.

[4] Super, D.E. (1957). The Psychology of careers. New York: Harper \& Row.

[5] Stumpf Stephen A. et al. (1983). Development of the Career Exploration Survey (CES). Journal of Vocational Behavior 22, 191-226.

[6] Stumpf Stephen A. et al. (1984). The Impact of Career Exploration and Interview Readiness on Interview Performance and Outcomes. Journal of Vocational Behavior 24, 221-235.

[7] Berlyne, D.A., (1960), Conflict, arousal, and curiosity. New York: McGraw-Hill.

[8] Berlyne, D.A., (1963), Motivational problems raised by exploratory and epistemic behavior. In S. Koch (Ed.), Psychology - A study of a science. New York: McGraw Hill, vol. 5.

[9] Berlyne, D.A., (1965), Structure and direction in thinking. New York: Willey.

[10] Jordan, J.P (1963). Exploratory behavior: The formation of self and occupational concepts. In D.E. Super, R. Statishersky, N. Martin, \& J.P. Jordan (Eds.), Career development: Self-concept theory. New York: College Entrance Examination Board.

[11] Atkinson G., Patricia H.M., (1988). Kolb's Experiential Learning Theory: A Meta-Model for Career Exploration. Journal of Counseling and Development vol. 66, Available at http://ausweb.scu.edu.au/aw05/papers/ refereed/soon/paper.html.

[12] Levi, M., Ziegler, S. (1993). The role of career exploration as a component of an effective guidance program in the transition. Guidance \& Counseling”, 8, pp. 6-15, 1993.

[13] Blustein, D. L., \& Flum, H. (1999). A self- determination perspective of interests and exploration in career development. In M. L. Savickas, \& A. R. Spokane (Eds.), Vocational interests: Meaning, measurement, and counseling use (pp. 345-368). Palo Alto, CA: DaviesBlack Publishing.

[14] NHDE: Concord, (2000), "Curriculum Development Framework”. New Hampshire: NHDE, 2000. Cranston, RI: Carole Press.

[15] Erik J. Porfeli \& Vladimir B. Skorikov, (2010). Specific and Diversive Career Exploration During Late Adolescence. Journal of Career Assessment.

[16] Lowe, A \& Toney, M. (2002). Academic Advising: Views of the Givers and the Takers. Journal of College Student Retention. 2 (12), 93-108, 2001-2002.

[17] Andreas Blom. \& Hiroshi Saeki., (2012). Employability and Skill Sets of Newly Graduated Engineers in India: A Study. The IUP Journal of Soft Skills, Vol. VI, No. 4, pp. 7-50, December 2012.Available at SSRN: http://ssrn.com/abstract=2187227.

[18] Stone J., (2011). College and Career Ready: A Conceptual Framework for increasing engagement, achievement and transition. Education and Employers Taskforce, London, paper presented at the 2nd Education and Employers Taskforce Research Conference, viewed Aug, 19th 2015. http://www.educationandemployers.org/media/13877/jam es_stone_iii_conference_paper_2011.pdf.

[19] Chithra. R, (2013). Employability Skills -A Study on the Perception of the Engineering Students and their Prospective Employers. Global Journal of Management and Business Studies. ISSN 2248-9878, Volume 3. pp. 525-534. 
[20] SAHDS (2013) Report No. 57 (South East Asia Human Development Sector). International Comparative Study: Engineering Education in India.

[21] OECD (2015), OECD Skills Outlook 2015: Youth, Skills and Employability, OECD Publishing. http://dx.doi.org/10.1787/9789264234178-en.

[22] Sakar V. Kamarthi et. al, (1992). ADVISOR-An Expert System for the Selection of Courses. Expert Systems with Apllications. Vol. 5, pp. 153-165, 1992.

[23] Denise F. \& Christine, (2000). Career Exploration: A Multivariate Analysis of Predictors. Journal of Vocational Behavior 56, 63-81.

[24] Janice W. \& Maggie B., (2005). Career Planning and Development for Students: Building a Career in a Professional Practice Discipline. Canadian Journal of Career Development. Volume 4.

[25] Esters Levon T. (2008). Influence of career exploration process behaviors on agriculture students' level of career certainty. Journal of Agricultural Education Volume 49, Number 3, pp. 23 - 33.

[26] Kelly K. Pargett, (2011). The Effects of Academic Advising on College Student Development in Higher Education. University of Nebraska: Thesis.

[27] Stephanie R. Easterday, (2013). Academic advising: a study of the impact of academic advising on student satisfaction. Rowan University: Thesis.

[28] Adeel K. \& Jessica W., (2014). Role of Academic Advisors in the Success of Engineering Students. Universal Journal of Educational Research 2(1): 73-79.

[29] Alavi, M., \& Leidner, D. E. (2001). Review: Knowledge Management and Knowledge Management Systems: conceptual foundations and research issues. MIS Quarterly, 25(1), 107-136.

[30] Rao R. Nemani (2010). The Role of Computer Technologies in Knowledge Acquisition. Journal of Knowledge Management Practice, Vol. 11, No. 3, September 2010.

[31] Lisa Soon (2005), a Comparative Study: Corporate Information Portals and Corporate Knowledge Portals.

[32] Liebowitz, J. (2000). Building Organizational Intelligence: A Knowledge Management Primer. Boca Raton, Florida: CRC Press LLC.

[33] Abell, A., \& Oxbrow, N. (2001). Competing with Knowledge: The Information Professional in the Knowledge Management Age. London, U.K.: Library Association Publishing.

[34] Ezingeard, J., Leigh, S., \& Chandler-Wilde, R. (2000). Knowledge management at Ernst \& Young UK: getting value through knowledge flows. Paper presented at the Proceedings of the Twenty First International Conference on Information Systems, Brisbane, Queensland, Australia.

[35] Mack, R., Ravin, Y., \& Byrd, R. J. (2001). Knowledge Portals and the Emerging Digital Knowledge Workspace. IBM Systems Journal, 40(4), 925-941.

[36] Rusli Abdullah et. al., (2005). A Framework for Knowledge Management System Implementation in Collaborative Environment for Higher Learning Institution. Journal of Knowledge Management Practice.

[37] Kimiz Dalkir (2013). Knowledge Management in Theory and Practice. McGill University.

[38] Zaied et. al., (2012). The Role of Knowledge Management in Enhancing Organizational Performance. I.J. Information Engineering and Electronic Business, 2012, 5, 27-35 Published Online October 2012 in MECS (http://www.mecs-press.org/)

DOI:10.5815/ijieeb.2012.05.04
[39] Alison \& Stephen, (2002). Knowledge management in careers services: implications for Connexions managers. Career Development International.

[40] Kimberly Gustafson, (2003). A Case Study: Knowledge Management Systems to Enhance a Nursing Curriculum. 36th Annual Communicating Nursing Research Conference/17th Annual Western Institute of Nursing Assembly in Scottsdale, Arizona.

[41] Balirwa, Moses, (2006). An information portal for career guidance: the case of ordinary level in Uganda. http://hdl.handle.net/10570/505

[42] Oktri \& Kadarsah, (2006). Nurse Knowledge Management Based On Expert System. Interdisciplinary Journal of Information, Knowledge, and Management Vol 1.

[43] Marjan M \& Norizan M.Y. (2010). Web portal As A Knowledge Management System In The Universities. World Academy of Science, Engineering and Technology 702010.

[44] Anand k (2011). Design and development of meta-model for knowledge management in higher education domain. Thesis: Anna University.

[45] Parul D. et. al (2011). Enhancing Curriculum and Research in Higher Education with a Strategic Use of Knowledge Management. Global Journal of Management and Business Research Volume 11 Issue 12 Version 1.0 December 2011.

[46] NKC (2009). National Knowledge Commission-Report to the Nation 2006 - 2009. Govt. of India.

[47] Ulka Toro \& Milind J. J, (2013). A Review of Literature on Knowledge Management using ICT in Higher Education. Int.J.Computer Technology \& Applications, Vol 4 (1), 62-67.

[48] Kathleen K. Molnar \& Ramesh Sharda, (1999). Using the Internet for knowledge acquisition in expert systems development: A case study.

[49] YU Jianli \& Qu Bo (Retrieved on 14 Jan. 2015). The Development of Career Management in the Knowledgebased Economy Era. Available at http://www.seiofbluemountain.com/upload/product/20100 1/12645783024w2ciysp.pdf.

[50] Arumugam Rathinavelu, (Accessed Aug 21, 2015). Design of KMS for Hr Education: Study. Available at http://www.tekbos.com/admin/upload/resources/Design\% $20 \mathrm{of} \% 20$ Knowledge $\% 20$ Management $\% 20$ System $\% 20$ for $\%$ 20higher\%20education.pdf.

[51] Fact Guru (2003). Frequently Ask Questions. [Online]Available:http://www.site.uottawa.ca:4321/faq.ht $\mathrm{m}$.

[52] Varekan K., Renukadevi (2012). Career Exploration needs of Engineering Education. International Journal of Computer Science \& Information Technology. IJCST Vol. 3, Issue 1, pp.586-588, Jan. - March 2012.

[53] Biswas (2012). South is the leader of engineering education. Available http://www.newindianexpress.com/education/edex/article 417565.ece.

[54] Bartley \& Robitschek (2000). Career Exploration: A Multivariate Analysis of Predictors. Journal of Vocational Behavior 56, 63-81. 


\section{Authors' Profiles}

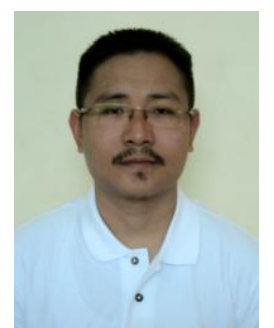

Varekan Keishing is a full-time Research Scholar (Ph.D in Computer Application and Engineering Education) at National Institute of Technical Teachers Training \& Research, Chennai, India. He has attended international \& national conferences. He has published some research paper in international journal. His area of research interest are Knowledge Management, Big Data, Computer Network, Emotional Intelligence \& Educational Psychology etc. He completed Bachelor of Computer Application in 2006, Master of Computer Application in 2009 from Madras University, Tamilnadu, India.

Dr. S. Renukadevi is a Professor and Head i/c of Department of Education, National Institute of Technical Teachers Training \& Research, Chennai, India. She specialized in Computer Application, Artificial Intelligence, Instructional Design, Pedagogy, Women Empowerment, Educational Management, Soft skill and Educational Psychology etc. She has organized various national and international conferences and has published many valuable research papers in various national and international Journals of repute.

How to cite this paper: Varekan Keishing, S. Renukadevi,"A Review of Knowledge Management Based Career Exploration System in Engineering Education", International Journal of Modern Education and Computer Science(IJMECS), Vol.8, No.1, pp.8-15, 2016.DOI: 10.5815/ijmecs.2016.01.02 